\title{
PERAN TEKNOLOGI DALAM PENENTUAN KEBIJAKAN PENGELOLAAN SUMBERDAYA AIR NASIONAL
}

\author{
Arie Herlambang \\ Pusat Teknologi Lingkungan, BPP Teknologi \\ JI. MH. Thamrin No. 8 Jakarta Pusat
}

\begin{abstract}
In the national water resource management, the data is the basis for the calculation of water reserves. In a large scale and wide, searching the data will require substantial funding, as well as with the updates. Data colecting becomes a problem and not useful if not managed with the system efficiently and effectively. Technology occupies an important role in accelerating the work, such as remote sensing technology using a satellite to determine the condition of forests and water, or a weather that can see the concentration of clouds and wind movement. Determination of catchment areas of water and protected areas, may of them using remote sensing technology. Water treatment technologies for drinking water and the development of efficient recycling technology of waste water, is very supportive in increasing water use efficiency. Technological developments also influence government policy and the implementation of water resource management. National Policy of Water Resource Management is influenced by economic factors, environmental sustainability and socio-cultural conditions. The role of technology are facilitate, accelerate and improve the efficiency of the process, so that the process can be more economical and environmental impact is reduced, and does not conflict with the socio-cultural conditions.
\end{abstract}

Keywords : Kebijakan nasional sumber daya air, potensi sda, teknologi pengolahan air

\section{PENDAHULUAN}

\subsection{Latar Belakang}

Pada tahun 1995, Ismail Seralgeldin, wakil presiden Bank Dunia, mencatat semacam prediksi mengenai masa depan perang: "Jika perang abad ini banyak diakibatkan oleh persengketaan minyak, perang masa depan akan dipicu oleh air."1 Cerita kekurangan air tidak hanya terjadi di Indonesia, tetapi terjadi juga di Israel, India, Bolivia, Cina, Kanada, Meksiko, Ghana, dan Amerika Serikat. New York Times (16 April 2001), mengangkat feature tentang kelangkaan air di Texas, sebagaimana Seralgeldin, bahwa Texas kini bukan minyak yang menjadi cairan emas, melainkan air.

Potensi dan ketersediaan air di Indonesia saat ini diperkirakan sebesar 15.000 meter kubik perkapita pertahun. Jauh lebih tinggi dari ratarata pasokan dunia yang hanya 8.000 $\mathrm{m}^{3} / \mathrm{kapita/tahun}$. Pulau Jawa pada tahun 1930 masih mampu memasok $4.700 \mathrm{~m}^{3} / \mathrm{kapita} / \mathrm{tahun}$, saat ini total potensinya sudah tinggal sepertiganya (1500 m³/kapita/tahun). Pada tahun 2020 total potensinya diperkirakan tinggal 1200 $\mathrm{m}^{3} / \mathrm{kapita}$ tahun. Dari potensi alami ini, yang layak dikelola secara ekonomi hanya 35\%, sehingga potensi nyata dari tinggal 400 $\mathrm{m}^{3} / \mathrm{kapita} / \mathrm{tah} u n$, jauh dibawah angka minimum PBB, yaitu sebesar $1.000 \mathrm{~m}^{3} /$ kapita/tahun.
Padahal dari jumlah 35\% tersebut, sebesar $6 \%$ diperlukan untuk penyelamatan saluran dan sungai-sungai, sebagai maintenance low. Oleh karena itu pada tahun 2025, Internasional Water Institute, menyebut Jawa dan beberapa pulau lainnya termasuk dalam wilayah krisis air. ${ }^{2}$ Menurut Water Resources Development (1990), tahun 1990 Pulau Jawa sudah mengalami defisit air, dari kebutuhan 66.336 juta $^{3}$ /tahun hanya bisa tersedia 43.952 juta $\mathrm{m}^{3}$ /tahun. Joko Pitono (2003) juga mengkaji bahwa pada musim kemarau tahun 1993, $75 \%$ Pulau Jawa sudah mengalami kekeringan akibat defisit air dan defisit air meningkat pada tahun 2000 menjadi 56\%, suatu angka yang menghawatirkan dan perlu diwaspadai secermat mungkin.

Kantor Menteri Negara Lingkungan Hidup tahun 1997, dalam neraca airnya menyatakan bahwa secara nasional belum terjadi defisit air, tetapi khusus untuk Jawa, Bali sudah terjadi defisit sejak tahun 2000 dan tahun 2015 bertambah dengan wilayah Sulawesi dan NTT. ${ }^{3}$ (Lihat Tabel 1).

\subsection{Tujuan dan Saran}

Tulisan ini bertujuan untuk memberikan sumbangan Pemikiran Untuk Perencanaan Pemikiran Jangka Menengah dan Panjang bagi pengelolaan sumberdaya air Indonesia. 
Sedangkan sasarannya adalah Tercapainya pengelolaan sumber-daya air yang berkelanjutan, dengan mempertimbangkan kemampuan sumber-daya air, kebutuhan air dan kelestariannya untuk generasi mendatang.

\section{PERMASALAHAN}

\subsection{Konversi Lahan}

Sudah menjadi alasan klasik bahwa meningkatnya jumlah penduduk di Indonesia menyebab-kan tekanan sosial ekonomi terhadap lahan pertanian, indikasinya antara lain :

a. Rata-rata 50.000 ha lahan pertanian teknis setiap tahun dikonversikan menjadi lahan non-pertanian. Lahan pertanian kelas satu yang dikonversikan untuk penggunaan lahan non pertanian tersebut sangat sulit untuk dicari gantinya ditempat lain, karena lahanlahan yang tersisa tinggal lahan marginal yang miskin.

b. Untuk mengganti lahan subur 50.000 ha yang hilang diperlukan lahan marginal 250.000 ha agar produksi padi tidak berkurang. ${ }^{4}$

c. Kerusakan Daerah Aliran Sungai (DAS) semakin meningkat dari tahun ke tahun, khususnya di Pulau Jawa. Perubahan pola penggunaan lahan dari lahan pertanian ke lahan non pertanian mengakibatkan berkurangnya area hutan, semakin intensifnya pemanfaatan lahan dan kurangnya usaha konservasi tanah dan air, serta belum jelasnya arah dan implementasi pembangunan dalam mengatasi permasalahan sumberdaya air secara nasional.

d. Adanya fragmentasi pengelolaan antar instansi pemerintah dan sulitnya koordinasi.

e. Pengelolaan sumberdaya air yang masih berorientasi pada sisi penyediaan. f. Borosnya pemakaian air untuk pertanian, karena rendahnya efisiensi pemakaian air untuk sektor pertanian. Sebagai pengguna 80-90\% dari seluruh pemanfaat air. Sektor pertanian diperkirakan memakai air dengan efektif untuk pertumbuhan tanaman hanya 50-60\% pasok air yang diterimanya, selebihnya hilang pada waktu pengaliran di saluran dan digunakan tidak optimal di areal sawah. Apabila pada saat ini air yang dialokasikan untuk irigasi sekitar 4.000 $\mathrm{m}^{3} /$ detik, maka peningkatan efisiensi sebesar $10 \%$ saja akan menghemat air $400 \mathrm{~m}^{3} /$ detik.

g. Masih tersentraliasasinya organisasi pengelolaan sumberdaya air dan kurangnya pelibatan masyarakat setempat.

Kondisi demikian menyebabkan semakin meningkatnya kerusakan sumberdaya alam dan lingkungan, seperti banjir, kekeringan, pencemaran, eutrofikasi, sedimentasi dan sebagainya.

\subsection{Management}

Disamping itu dalam isu permasalahan pengelolaan sumber daya air pada RPJMN 20042009 adalah :

a. Ketidakseimbangan antara pasokan dan kebutuhan air dalam perspektif ruang dan waktu;

b. Ancaman yang meningkatnya terhadap keberlanjutan daya dukung sumber daya air, baik air permukaan maupun air air tanah;

c. Kemampuan penyediaan air menurun;

d. Potensi konflik air meningkat;

e. Tingkat layanan irigasi kurang optimal;

f. Abrasi pantai meluas

g. Koordinasi dan ketatalaksanaan lemah; dan kualitas pengelolaan data dan sistem informasi yang rendah.

Tabel 1. Ketersediaan dan kebutuhan air m enurut pulau di Indonesia

\begin{tabular}{|c|c|c|c|c|c|c|c|c|}
\hline \multirow[t]{2}{*}{ No } & \multirow[t]{2}{*}{ Pulau } & \multirow{2}{*}{$\begin{array}{l}\text { Keterse- } \\
\text { dagn Air } \\
\text { (juam3th) }\end{array}$} & \multicolumn{3}{|c|}{$\begin{array}{l}\text { Kebututhan Air } \\
\text { (uta m 3ith) }\end{array}$} & \multicolumn{3}{|c|}{$\begin{array}{c}\text { Surplus/Deisit Air } \\
\text { (juta m3.th) }\end{array}$} \\
\hline & & & 1995 & 2000 & 2015 & 1995 & 2000 & 2015 \\
\hline 1 & Sumatera & 111077,7 & $19.164,8$ & $25.297,5$ & $49.583,2$ & $91.912,9$ & $\otimes 5.7 \otimes 0,2$ & $61.494,5$ \\
\hline 2 & Janua & $30.569,2$ & $62.927,0$ & $\otimes 3.37 \otimes, 2$ & $164.672,0$ & $-32357,8$ & $-52.809,0$ & $-134.102,8$ \\
\hline 3 & Kaimantan & 140005,6 & $5.111,3$ & $8.203,6$ & $23.093,3$ & $134.94,3$ & $131 \otimes 02,0$ & $116.912,3$ \\
\hline 4 & Suanesi & $34.7 \otimes 7,6$ & $15.257,0$ & $25.555,5$ & $77.305,3$ & $19.530,6$ & $9.232,1$ & $-42.517,7$ \\
\hline 5 & Bali & $1.067,3$ & $2.574,4$ & $8.598,5$ & $28.719,0$ & $-1.507,1$ & $-7.531,2$ & $-27.651,7$ \\
\hline 6 & NTB & $3.50 \otimes, 6$ & $1.628,6$ & 1.8322 & $2.519,3$ & $1 . \otimes 0,0$ & $1.676,4$ & $\$ \otimes 9,3$ \\
\hline 7 & लाT & $4.251,2$ & $1.736,2$ & $2.90 \otimes, 1$ & $8.797,1$ & $2.515,0$ & $1.343,1$ & $-4.545,9$ \\
\hline 8 & Maluku & $15.457,7$ & 235,7 & 3052 & 575,4 & $15.222,0$ & $15.152,5$ & $14 \otimes 2,3$ \\
\hline 9 & Papua & 350589,7 & $12 \otimes, 3$ & $2 \otimes 3,4$ & $1.310,6$ & $350.461,4$ & $350,306,3$ & $349.279,1$ \\
\hline & hodonesia & 691314,6 & $108.7 \Subset 3,3$ & $156.362,2$ & $356.575,2$ & $5 \& 2.551,3$ & 534952,4 & $334.739,4$ \\
\hline
\end{tabular}




\section{USAHA PERBAIKAN}

\subsection{Penyelamatan Hutan}

Penyelamatan sumberdaya hutan, tanah dan sumberdaya air di Indonesia sudah dilakukan sejak tahun 1961, dengan gerakan penghijauan secara massal dalam bentuk pekan penghijauan pertama di Gunung Mas, Puncak, Bogor. Uji coba untuk memperoleh metode yang tepat dalam rangka rehabilitasi lahan dan konservasi tanah ditinjau dari aspek fisik dan sosial ekonomis, juga dilakukan pada tahun 1973 sampai tahun 1981 di hulu DAS Bengawan Solo. Hasil pengujian antara lain diterapkan dalam proyek-proyek Inpres Penghijauan dan Reboisasi sejak tahun 1976 pada 36 DAS di Indonesia.

\subsection{Pengelolaan DAS Terpadu}

Kerusakan DAS terus meningkat dengan cepat. Jika pada tahun 1984 terdapat kerusakan 22 DAS kritis dan super kritis, tahun 1992 meningkat menjadi 29 DAS, 1994 menjadi 39 DAS, 1998 menjadi 42 DAS, 2000 menjadi 58 DAS dan tahun 2003 menjadi 62 DAS yang rusak super kritis dan kritis. Diperkirakan 13\% dari 458 DAS di Indonesia dalam kondisi kritis saat ini.

Berdasarkan citra satelit Landsat tahun 2000 , luas lahan kritis dan kerusakan hutan di Indonesia mencapai 54,65 juta hektar yang terdiri dari 9,75 juta hektar hutan lindung, 3,9 juta hektar hutan konservasi dan 41 juta hektar hutan produksi. Sedangkan kerusakan lahan di luar kawasan hutan mencapai 41,69 juta hektar. Laju kerusakan hutan terus meningkat setiap tahunnya. Sebelum diberlakukannya otonomi daerah, yakni pada periode 1995 - 1997, laju kerusakan hutan mencapai 1,6 juta hektar per tahun, namun setelah reformasi dan otonomi daerah kerusakan lebih besar yaitu mencapai 2,3 juta hektar per tahun.

Pengelolaan DAS sudah dilakukan sejak tahun 1969 hingga sekarang, namun demikian kerusakan DAS terus meningkat. Salah satu faktor penyebab kegagalan adalah mekanisme yang top-down dan belum terpadunya pengelolaan DAS. Faktor eksternalitas dalam konservasi DAS selalu menimbulkan masalah karena tidak adanya azas keadilan. Masyarakat di hulu dituntut untuk mengkonservasi dan dibatasi pembangunnya, namun yang menikmati justru masyarakat di hilir. Belum adanya peraturan perundangan yang mengatus mekanisme insentif dari hilir ke hulu menyebabkan ketidakberhasilan di dalam pengelolaan DAS.

Upaya pengelolaan DAS terpadu pertama dilaksanakan di DAS Citandui pada tahun 1981, dimana berbagai kegiatan lintas sektoral dan lintas disiplin dilakukan. Selanjutnya pengelolaan DAS terpadu dilakukan di DAS Brantas dan Jratunseluna. Kegiatan konservasi tanah untuk mencegah erosi dan banjir seluruhnya dibiayai oleh pemerintah. Konsep partisipasi mulai diterapkan tahun 1994, dalam penyelenggaraan Inpres penghijauan dan reboisasi, walaupun masih dalam taraf perencanaan.

\subsection{Koordinasi}

Dalam rangka untuk penanganan DAS prioritas sudah ada keputusan tiga menteri, yaitu : Menteri Dalam Negeri, Menteri Kehutanan, dan Menteri Pekerjaan Umum, tertanggal 4 April 1984, yang menyatakan adanya 22 DAS superprioritas ${ }^{5)}$. Dasar penetapan DAS superprioritas didasarkan pada :

a. Daerah yang hidroorologisnya kritis, ditandai oleh besarnya angka perbandingan antara debit maksimum (musim hujan) dan minimum (kemarau) serta kandungan lumpur (sedimen load) yang berlebihan.

b. Daerah yang sedang atau akan dibangun bangunan vital dengan investasi besar, antara lain bendung atau tanggul.

c. Daerah yang rawan terhadap banjir dan kekeringan.

d. Daerah perladangan berpindah usaha kepadatan penduduk.

Namun demikian usaha itu tidak dapat meminimumnkan kerusahan DAS, bahkan DAS superprioritas menjadi 39 DAS pada tahun 1998. dan tahun 2000 meningkat hingga 58 DAS. Bapenas tahun 2000, membuat sembilan agenda yang tercakup dalam upaya pembaharuan kebijakan, yaitu :

a. Membentuk wadah nasional sumberdaya air (semacam Badan Air Nasional),

b. Merumuskan kebijakan air nasional,

c. Menyesuaikan undang-undang dan peraturan pemerintah,

d. Memperkuat sistem koordinasi kelembagaan sumberdaya air baik pada tingkat propinsi maupun pada tingkat wilayah sungai,

e. Membentuk kerangka sistem informasi dan jaringan data sumberdaya air,

f. Menyelenggarakan korporitasi pengelolaan wilayah sungai,

g. Mempersiapkan kerangka kerja untuk alokasi air yang adil dan efisien dan mekanisme hak guna air untuk air permukaan dan air tanah,

h. Membentuk kerangka peraturan yang efektif dan dapat dijalankan untuk mengendalikan pencemaran air dan pengelolaan kualitas air.

i. Merevisi kebijakan, kelembagaan, dan peraturan untuk meningkatkan manajemen irigasi. 


\subsection{Kesepakatan Internasional}

Dalam kesepakatan Den Haag, mengenai air, maret 2000, telah disepakati oleh para menteri dari negara peserta tujuh tantangan pokok pengenai pengelolaan air, sebagai berikut :

a. Mengutamakan penggunaan air untuk memenuhi kebutuhan pokok manusia akan air minum yang bersih;

b. menjamin tersedianya air bagi produksi pangan;

c. melindungi fungsi air dalam mendukung berlanjutnya kehidupan ekosistem;

d. mengusakan pembagian sumber air seadil mungkin bagi sebanyak mungkin manusia yang memerlukan di bumi ini;

e. Mengelola resiko yang berkaitan guna menjamin keberlanjutan air bersih;

f. memberi nilai kepada air agar dapat secara jelas diketahui biayanya. Jika dipandang perlu untuk membantu kelompok penduduk miskin subsidi air minum, maka ini bisa dilakukan berdasarkan nilai air yang riel. $\mathrm{Di}$ lain fihak kelompok penduduk yang mampu atau menggunakannya untuk tujuan komersil perlu membayar biaya air secara penuh, bahkan atas dasar biaya plus;

g. membangun badan yang mengelola air secara berkelanjutan memenuhi kebutuhan generasi kini tanpa mengurangi kesempatan bagi generasi masa depan untuk dapat memanfaatkan air.

Dalam kesepakatan pembangunan yang berkelanjutan di Johanesburg 2002 dan Agenda 21 ada tiga pilar utama yang harus diperhatikan dalam melakukan pembangunan, yakni 6) : pembangunan sosial, pertumbuhan ekonomi, dan perlindungan lingkungan. Tujuan utamanya adalah penghapusan kemiskinan dan pengubahan pola konsumsi dan produksi untuk melindungi keberlanjutan lingkungan.

Dalam era globalisasi pengaruh dari luar demikian besarnya, oleh karena itu diperlukan suatu lingkungan ekonomi yang dinamis berdasarkan kerjasama internasional, terutama menyangkut aspek finansial, alih teknologi, dan partisipasi penuh dari Negara berkembang dalam pengambilan keputusan global. Keamanan, ketahanan, dan stabilitas amat diperlukan untuk melaksanakan semua usaha tersebut. Ada beberapa kesepakatan sasaran dalam penghapusan kemiskinan yang perlu diketahui, yakni, bahwa pada tahun 2015 jumlah orang miskin dengan pendapatan kurang dari US\$1, yang kelaparan dan mendapat akses terhadap air minum yang aman (bersih), harus direduksi setengahnya.

Separuh dari jumlah penduduk miskin sedunia yang tidak dijangkau oleh fasilitas air minum bersih harus sudah terpenuhi dengan upaya-upaya:

a. Mengusahakan berbagai sumber pembiayaan,

b. Alih Teknologi untuk memungkinkan tercapainya sasaran ini terutama bagi yang miskin dan perempuan,

c. Secara aktif melibatkan masyarakat dan khususnya perempuan dalam rangka penyusunan kebijakan, pengambilan keputusan, dan pengelolaan sumberdaya air dan

d. Mencegah pencemaran air dalam rangka pengembangan air bersih dengan teknologi bersih 7 .

Sedangkan sasaran tahun 2005 adalah setiap negara perlu menyepakati langkah tindakan pengelolaan sumberdaya air secara terintegrasi, efisien, dan mendorong penggunaan air secara sustainable serta memecahkan masalah kekurangan air di kawasannya, yang dilaksanakan melalui;

a. Pengembangan Daerah Aliran Sungai (DAS) secara terintegrasi.

b. Pengelolaan air tanah,

c. Menerapkan usaha mengefisienkan penggunaan air.

d. Merangsang pendaur ulangan air,

e. Mengembangkan berbagai instrumen kebijakan yang mencakup; pengaturan, pemantauan, langkah sukarela, informasi, pengelolaan tataguna lahan dan ruang, perolehan biaya recovery, dan pendekatan daerah aliran sungai,

f. Menggali dan mengusahakan difusi teknologi dan pengembangan kapasitas untuk caracara inkonvensional dalam konservasi air,

g. Mengusahakan desalinasi air laut, daur ulang air, dan menuai air dari kabut pantai perlu diusahakan melalui kerjasama teknologi dan pendanaan antar negara,

h. Mengembangkan kemitraan publik-privat atau bentuk kemitraan lain yang sesuai, dengan memprioritaskan air untuk penduduk miskin.

i. Meningkatkan pengelolaan sumberdaya air dan pemahaman daur air melalui; penelitian penelitian yang diperluas, dan pengkajian teknologi, antara lain remote sensing dan teknologi satelit dan

j. Mematok tahun 2003 sebagai Tahun Internasional untuk Air Bersih dan menggalakkan kerjasama nasional, regional, dan global untuk menyelamatkan dan mengembangkan sumberdaya air. Berkerkaitan dengan adanya kesepakatankesepakatan internasional tersebut, diperlukan upaya pembaharuan pengelolaan sumberdaya air Indonesia. 


\section{KONSEP KEBIJAKAN}

Dalam $2^{\text {nd }}$ Word Water Forum 2000, telah disarankan agar Intergrated Water Resource Management (IWRM) menjadi prinsip dasar pengembangan dan pengelolaan Sumberdaya Air. Pengertian dan Prinsip-prinsip dasar IWRM adalah suatu proses yang mengedepankan pembangunan dan pengengelolaan sumberdaya air, lahan, dan sumberdaya terkait lainnya secara terkoordinasi dalam rangka memaksimalkan resultan ekonomi dan kesejahteraan sosial secara adil tanpa mengorbankan keberlanjutan ekosistem yang vital (Global Water Partnership, 2000) adapun prinsip-prinsip dasarnya keterpaduan dalam IWRM mencakup dua komponen utama, yaitu :

1. keterpaduan pada sistem alam (natural system); dan

2. keterpaduan pada sistem manusia (human system).

Keterpaduan sistem alam, mencakup enam aspek keterpaduan, yakni;

1. Keterpaduan berbagai kepentingan daerah hulu dan daerah hilir,

2. Keterpaduan pengelolaan kualitas dan kuantitas,

3. Keterpaduan pengelolaan air permukaan dan air bawah tanah,

4. Keterpaduan penggunaan lahan dan pengelolaan siklus hidrologis,

5. Keterpaduan pengelolaan green water dan blue water; dan

6. Keterpaduan pengelolaan air tawar dengan daerah pantai.

Keterpaduan sistem manusia mencakup

sedikitnya tiga aspek keterpaduan :

1. Keterpaduan kebijakan nasional antar sektor;

2. Keterpaduan seluruh stakeholders dalam perencanaan dan pengambilan keputusan; dan

3. Keterpaduan antara pengelolaan air dan air limbah.

Adapun Kriteria utama keterpaduan, adalah ;

1. Efisiensi ekonomi berkaitan dengan kelangkaan air, terbatasnya pembiayaan, dan pencemaran air;

2. Keadilan berkaitan dengan hak setiap orang untuk mempunyai akses dan memenuhi kebutuhan akan air sebagai kebutuhan dasarnya; dan

3. Keberlanjutan (sustainability) lingkungan dan ekologi, sehingga tidak mengorbankan kepentingan generasi yang akan datang.

Pengelolaan sumber daya air yang hanya demi pertumbuhan ekonomi menjadikan hukum alam sebagai hukum pinggiran yang bisa diabaikan. Padahal, hukum alam memiliki kearifan, dan dalam kearifan itu ia berjalan secara konsisten, tak pernah berhenti, impersonal, dan tanpa kompromi. la bahkan tidak kenal keadilan dan tatanan ekonomi-politik buatan manusia. Hukum alam juga menciptakan sumber daya yang tidak mungkin menjadi hak perorangan. Dengan hukumnya sendiri bahkan menentukan batas yurisdiksi wilayah, kesatuan perencanaan dan pemanfaatan wilayah, karena itu kebijakan menguras Sumber Daya Air tanpa memperhatikan daya dukungnya jelas akan diadili hukum alam itu sendiri?.

Jika ditinjau dari sistem air yang ada, secara hidrolologi (earth system) volume air yang berputar tidak banyak perubahan, yang berubah adalah perilaku manusianya (man made system) dan tidak berjalannya sistem hukum yang mengatur lingkungan sumberdaya air (legal system), sehingga akibat terganggunya daerah resapan, air lebih banyak mengalir dipermukaan dan menimbulkan banjir di beberapa tempat, sedangkan akibat perkembangan industri dan peningkatan jumlah penduduk menimbulkan ekploitasi air yang berlebihan dan pencemaran sumber air akibat limbah yang tidak dikelola dengan baik (Gambar 1).

Dalam sistem manusia yang terkait dengan aspek air, berjalannya sistem dipengaruhi oleh keterkaitan yang erat antara sistem sosial, sistem ekonomi, sistem keteknisan (rancang bangun) dan sistem hukum yang mengaturnya. Kegiatan pada sistem ekonomi yang tidak ditunjang dengan sistem hukum dan sosial yang baik dapat menimbulkan kerusakan pada sumberdaya air yang ada, karena akan terjadi ekploitasi yang berlebihan.

Untuk meningkatkan daya tahan suatu wilayah terhadap ketersediaan air, ditinjau dari segi sistem, harus ditunjang dengan adanya bendungan atau reservoir yang berfungsi menampung kelebihan air selama musim hujan dan sebagai cadangan air ketika musim kemarau, pengolah air yang kapasitasnya sudah memperhitungkan kebutuhan masa kini dan mendatang, penampungan air bersih, sistem perpipaan air bersih ke konsumen, dan sistem pengolahan air limbah dan pembuangan air yang baik (Gambar 2). Semua kegiatan atau aktivitas memerlukan air, oleh karena itu perlu pengaturan agar tidak terjadi perebutan sumberdaya air akibat perang kepentingan yang pada akhirnya masyarakat menjadi korban ketidakadilan pembagian sumberdaya air.

Dalam rangka pengelolaan sumberdaya air, maka dibuatlah suatu undang-undang, yaitu Undang-Undang Sumberdaya Air Nomor 7 Tahun 2004. Undang-Undang Sumberdaya Air muncul sebagai tuntutan perkembangan keadaan, dan perubahan dalam kehidupan di masyarakat, sehingga UU No. 11 Tahun 1994 tentang pengairan dianggap sudah tidak sesuai lagi. Prediksi kelangkaan sumber air di beberapa 
wilayah di Indonesia pada tahun-tahun mendatang, adanya musibah banjir pada musim hujan dan kekeringan yang datang setiap tahun merupakan indikasi perlunya pengaturan sumberdaya air secara lebih tersistematis baik dari segi teknis, ekonomis, sosial, budaya, lingkungan maupun dari aspek legal.

Air pada masa yang akan datang cenderung menjadi sesuatu yang langka. Angkaangka yang ada menunjukkan kecenderungan kelangkaan air, baik dari kualitas maupun kuantitas. Secara ekonomis kelangkaan merupakan salah satu faktor yang menyebabkan nilai barang menjadi lebih berharga, apalagi jika dibutuhkan orang banyak. Secara perlahan air akan bergeser dari nilainya, terutama pada daerah-daerah yang mempunyai kepadatan penduduk tinggi.

Undang-Undang Sumberdaya air diperlukan untuk mengatur pemanfaatan air, agar sumberdaya air yang ada dapat dimanfaatkan, dipelihara dan dijaga secara berkelanjutan sampai pada generasi yang akan datang. Adanya harapan dari masyarakat untuk hadirnya undang-undang sumberdaya air yang berwawasan lingkungan merupakan indikasi berhasilnya pembangunan di bidang lingkungan. Namun fakta bahwa sumberdaya air tidak merata untuk semua tempat, oleh karena itu diperlukan pengaturan yang terkadang bertentangan dengan konsep-konsep daya dukung lingkungan.

\section{TEKNOLOGI TPSDA}

Teknologi Pengelolaan Sumber Daya Air (TPSDA) diperlukan untuk meningkatkan efisiensi pengelolaan SDA, melalui peningkatan akurasi dan presisi dalam inventarisasi potensi SDA, perencanaan alokasi SDA, pengaturan keadilan dalam penggunaan, kemudahan dan kecepatan dalam pemantauan SDA, penghematan SDA, Efisiensi Pengolahan Limbah, Efisiensi Proses Daur Ulang, dan Kemudahan dalam evaluasi SDA.

\subsection{Teknologi Inventarisasi SDA}

Berdasarkan neraca air yang ada, perlu diprioritaskan aplikasi teknologi inventarisasi SDA untuk menjamin keberadaan cadangan air untuk masa kini dan masa mendatang, teknologi yang umum dipakai antara lain :

a. Teknologi satelit dengan penginderaan jarak jauh (remote sensing) untuk mendeteksi awan, arah angin, temperatur, kelembaban, dll;

b. Teknologi radar untuk mendeteksi kepadatan awan dalam radius $25 \mathrm{~s} / \mathrm{d} 100 \mathrm{~km}$, dengan teknologi ini bisa diketahui mana daerah yang akan terjadi hujan dan kapan kejadian hujannya, sehingga mudah digunakan untuk mitigasi dan adaptasi bencana;

c. Teknologi seismik dan geolistrik : untuk mengetahui ketebalan dan penyebaran reservoir air bawah tanah.

d. Teknologi gravity dan mikrogravity untuk mengetahui tempat-tempat yang mempunyai ketebalan sedimen dan mengambarkan konfigurasi basement cekungan.

Mengingat luasnya wilayah Indonesia, investasi dibidang teknologi inventarisasi SDA ini penting dilakukan dan jika dilakukan dengan baik akan dapat mengkoreksi neraca air yang ada. Indonesia sebagai negara nomer lima terkaya dalam sumber daya air, tidak akan banyak manfaatnya jika tidak diketahui dengan pasti dimana potensi air tersebut berada.

\subsection{Perencanaan SDA}

\section{Perencanaan}

pembangunan membutuhkan informasi yang tepat mengenai potensi air di suatu wilayah. Ketersediaan data dan informasi menjadi basis dalam perencanaan, baik dalam jangka pendek dan jangka panjang. Dalam era sekarang ini kecepatan dalam mendeteksi cuaca sangat diperlukan, karena itu perubahan cuaca dapat terjadi dalam satu hari, bahkan jam. Penghitungan potensi air wilayah seharusnya tidak konstant sepanjang tahun, tetapi naik turun sesuai dengan musimnya. Oleh karena itu perencanaan penggunaan SDA sebaiknya sudah mempertimbangkan perubahan tersebut. Teknologi diperlukan untuk mempercepat mendeteksi adanya perubahan cuaca yang terjadi.

\subsection{Penggunaan SDA}

Standard penggunaan air untuk berbagai keperluan perlu ditinjau kembali besarannya. Dengan perkembangan dan perubahan gaya hidup dan kondisi ekonomi, sedikit banyak akan merubah konsumsi air, oleh karena itu perlu dikembangkan metodologi untuk menentukan besaran kebutuhan air untuk berbagai keperluan. Penentuan kelas sungai sesuai yang diamanatkan dalam PP 80 Tahun 2001 perlu segera direalisasikan, agar pengelolaan sumber daya air lebih terfokus dan management pengelolaan air sungai lebih terarah, daya dukung lingkungan lebih terkendali, sehingga diharapkan dalam penggunaannya tidak memerlukan banyak investasi untuk peningkatan kualitas. Teknologi pemanfaatan atau penggunaan SDA sebaiknya mempertimbangkan efisiensi proses, kemudahan operasional dan biaya dan kualitas proses, sehingga masyarakat dapat menikmati sumber daya air secara wajar, 
disamping biaya investasi dan UU No 7 Tahun 2004.

\subsection{Pemantauan SDA}

Teknologi pemantaua SDA diperlukan, untuk identifikasi kelebihan air dan kekurangan air. Kelebihan SDA dapat menimbulkan banjir atau luapan atau genangan pada suatu wilayah. Teknologi pemantauan dapat berupa teknologi radar cuaca atau menggunakan sistem monitoring konvensional dengan sistem radio atau satelit. Pemakaian teknologi monitoring digunakan untuk mitigasi dan adaptasi bencana. Pada musim kering, teknologi pemantauan radar lebih efektif digunakan karena dapat mendeteksi keberadaan awan pada suatu wilayah. Informasi ini diperlukan untuk membantu mengambil keputusan dalam menentukan lokasi hujan buatan pada suatu wilayah.

Teknologi monitoring air tanah yang ada saat ini hanya mengukur penurunan tinggi permukaan air tanah. Saat ini air tanah masih banyak digunakan diperkotaan, namun perlindungan sumberdaya air tanah belum optimal, sehingga terjadi "cone depresion" pada beberapa wilayah yang mempunyai kecenderungan makin parah dari tahun ke tahun. Oleh karena itu perlu dikembangkan sistem monitoring yang dilengkapi dengan "alert system" dengan mempertimbangkan tinggi muka air tanah yang aman untuk suatu wilayah.

\subsection{Penghematan SDA}

Kelangkaan SDA memerlukan langkah penghematan dalam pemakaian SDA. Pemilihan teknologi proses produksi harus mempertimbangkan kebutuhan air. Pada bagian ini agak sulit dilakukan karena pemilihan teknologi sangat tergantung pada pengguna, kecuali ada insentif dari penggunaannya.

\subsection{Pengolahan Limbah dan Daur Ulang}

Dengan meningkatnya jumlah penduduk, pencemaran menjadi persoalan rumit bagi pelestarian sumber air. Pengembangan dan aplikasi teknologi pengolahan limbah perlu dilakukan. Aplikasi teknologi pengolahan limbah akan meningkatkan daya dukung lingkungan. Daur ulang pemakaian air limbah untuk keperluan industri harus ditingkatkan agar keberadaan SDA suatu wilayah dapat terjaga dan dapat menjangkau untuk keperluan yang lebih luas. Setiap kegiatan yang menghasilkan limbah diwajibkan mengolah limbahnya dan daur ulang air minimal $30 \%$ untuk setiap pengguna yang memakai air dalam jumlah besar.

\subsection{Evaluasi Pengunaan SDA}

Evaluasi secara berkala perlu dilakukan, secara kuantitas dan kualitas. Evaluasi penggunaan SDA suatu wilayah perlu mempertimbangkan azas keadilan dan pemerataan penggunaan sumberdaya air. Perlu ditetapkan lembaga yang berwenang untuk melalukan evaluasi penggunaan air setiap tahun. Dalam evaluasi perlu ditetapkan parameter mana yang perlu diperbaiki dan ditingkatkan kualitasnya. Sistem informasi dan pengolahan data yang baik perlu dikembangkan agar proses evaluasi dapat cepat dilaksanakan.

\section{USULAN KEBIJAKAN}

Berdasarkan kondisi yang ada, perlu dilakukan kebijakan (usulan) agar pengelolaan sumber daya air dapat berkelanjutan, baik dalam jangka pendek maupun jangka panjang, antara lain :

\section{Jangka Pendek (Darurat)}

a. Aplikasi teknologi deteksi keberadaan awan dengan radar cuaca;

b. Aplikasi satelit cuaca untuk mitigasi dan adaptasi bencana banjir;

c. Aplikasi Teknologi Modifikasi Cuaca;

d. Aplikasi Teknologi Online Monitoring (Onlimo) untuk deteksi permukaan air sungai (untuk deteksi banjir), muka air tanah, dan pencemaran lingkungan.

\section{Jangka Menengah dan Panjang}

a. Pembangunan dan implementasi sumur resapan dan waduk resapan;

b. Rehabilitasi embung, situ, rawa, dan danau;

c. Pembangunan waduk penampung air dan pengendali banjir;

d. Reboisasi dan penghijauan dengan jenis tanaman yang mempunyai nilai ekonomis, bukan berorientasi kayu (tidak ditebang), jenis tanaman yang tidak rakus air (seperti Akasia, Sengon)

e. Prototipe pengelolaan sumberdaya air terpadu (IWRM), antara lain : penataan ruang berbasis ekosistem, pengembangan teknologi irigasi dan pertanian hemat air, dan lain-lain yang memenuhi prinsip dasar IWRM

f. Penerapan teknologi input hujan (modifikasi cuaca)

g. Penerapan teknologi sistem informasi iklim dan air 
h. Community Based Development : 1) Pengembangan Modernized Indigeneous Knowledge and Technology, 2) Sosialisasi untuk merubah budaya boros air, khususnya pada pertanian

i. Insentif silang antara hulu - hilir, mendesak munculnya Rancangan Undang-Undang Jasa Lingkungan.

j. Pengembangan teknologi ecohydraulic, khususnya di kawasan hulu tengah sungai dengan menahan air agar lebih lama tergenang dan mengalirkan secara perlahanlahan

k. Penyusunan peta baku (lahan kritis)

I. Pengelolaan DAS (one river, one plan, one integrated management)

$\mathrm{m}$. Evaluasi dan monitoring pengelolaan DAS yang accountable dan terukur (teknologi quick map, citra satelit, modeling DAS, evaluasi sistem habitat).

\section{USULAN PROGRAM PRIORITAS}

Beberapa program kegiatan prioritas yang dapat diusulkan atara lain :

1. Pengelolaan sumberdaya air harus tetap dikuasai oleh Negara melalui pembentukan Badan Air Nasional yang bertugas mengkoordinasikan seluruh pemangku kepentingan dalam pengelolaan sumberdaya air sesuai dengan amanat : 1) Ministerial Declaration of The Hague on Water Security in the $21^{\text {st }}$ Century, $2^{\text {nd }}$ World Water Forum 2000; 2) Rencana Implementasi Program Prioritas Air dari World Summit on Sustainable Development Johannesburg 2002, dan 3) World Water Forum 2003 di Kyoto.

2. Pengelolaan sumberdaya air oleh pihak swasta dimungkinkan seminimal mungkin dan pada kondisi dimana diperlukan investasi yang sangat besar. Selanjutnya perlu diterapkan pendekatan Depletion Premium terhadap industri pengelola air.

3. Kawasan hulu harus tetap dipertahankan sebagai ekosistem resapan air dengan menerapkan teknologi konservasi tanah dan air permukaan yang mempunyai nilai ekonomi tinggi terhadap masyarakat. Kawasan hilir dapat dimanfaatkan sebagai kawasan pengembangan ekonomi dengan memperhatikan aspek hidrologisnya. Perlu dilakukan subsidi silang untuk kegiatan konsevasi bagi masyarakat hulu. Selama ini, masyarakat hulu selalu dituntut untuk melakukan konservasi dan kegiatan ekonominya dibatasi, namun yang menikmati hasil justru masyarakat di hilir. Untuk itu perlu adanya insentif (misal dengan pajak) untuk diberikan pada masyarakat hilir untuk kegiatan konservasi.

4. Segera dibangun sistem informasi iklim dan hidrologi terpadu, terkini, reliable dan mudah diakses masyarakat.

5. Segera disusun dan dilaksanakan pengembangan Prototipe Pengelolaan Sumberdaya Air Terpadu (IWRM) dengan mengambil lokasi beberapa DAS kritis di Pulau Jawa.

6. Perlu dilaksanakannya Teknologi Modifikasi Cuaca (Hujan Buatan) di beberapa DAS di Jawa.

7. Perlu dibangun dan disosialisasikan penerapan teknologi sumur resapan dan waduk resapan.

\section{KESIMPULAN}

Kesimpulan yang dapat ditarik dari tulisan ini antara lain :

1. Dalam Pengelolaan Sumber Daya Air diperlukan teknologi untuk mempercepat proses, meningkatkan akurasi dan presisi dalam pengelolaan, mempermudah dalam pengambilan keputusan untuk melakukan mitigasi dan adaptasi bencana.

2. Pengelolaan Sumber Daya Air merupakan pekerjaan multi sektor, oleh karena itu leading sektor sebaiknya ditentukan berdasarkan pengguna terbesar dari air tersebut, karena didalamnya melekat tanggung jawabnya untuk menjaga kelestariannya.

\section{DAFTAR PUSTAKA}

1. Vandhana Shiva, 2002, Water Wars : Privatisasi, Profit, dan Polusi, Insist Press, Pogunglor C-145, Yogyakarta.

2. Djoko Pitono, 2003, Sumbangan Brantas Untuk Pembangunan Berkelanjutan, disajikan dalam Seminar Sistem Monitoring Pencemaran Lingkungan Sungai dan Teknologi Pengelolaannya, Hotel Panghegar, Bandung, 8-9 Juli 2003, Penyelenggara PPET, LIPI.

3. Sutopo Purwo Nugroho, Pengelolaan DAS dan Sumberdaya Air yang Berkelanjutan, 2002, Peluang dan Tantangan Pengelolaan Sumberdaya Air di Indonesia, hal 165.

4. Notohadiprawiro T, N. Rachman A Sutanto dkk., 1999, Kebutuhan Riset, Inventarisasi, 
dan Koordinasi Pengelolaan Sumberdaya Tanah di Indonesia, Kantor Menteri Negara Riset dan Teknologi, Dewan Riset Nasional.

5. Surat Keputusan Tiga Menteri; Menteri Dalam Negeri, Menteri Kehutanan, Menteri Pekerjaan Umum, No. 19 tahun 1984, No. 059/Pkts-II/1984 tentang Penanganan Konservasi Tanah dalam Rangka Pengamanan Daerah Aliran Sungai Prioritas.

6. Indreswari Guritno, Kebutuhan Riset dan Tantangan Pengelolaan Sumberdaya Air, Fakultas Teknik, Universitas Indonesia, 2002, hal 145.
7. World Summit on Sustainable Development Johannesburg 2002, Rencana Implementasi Program Prioritas Air.

8. ANDANG. S, 2002, Krisis Air Mengancam Jatim, Kompas, Rabu, 2 Oktober 2002, Antropolog, dosen Fakultas Sastra Universitas Jember.

9. Engelen, G.B., 1986, Water Systems, Methodology and Definitions, Development in the analysis of groundwater flow systems, the Internasional Association of hydrological sciences, UK, Hal. 68-69. 

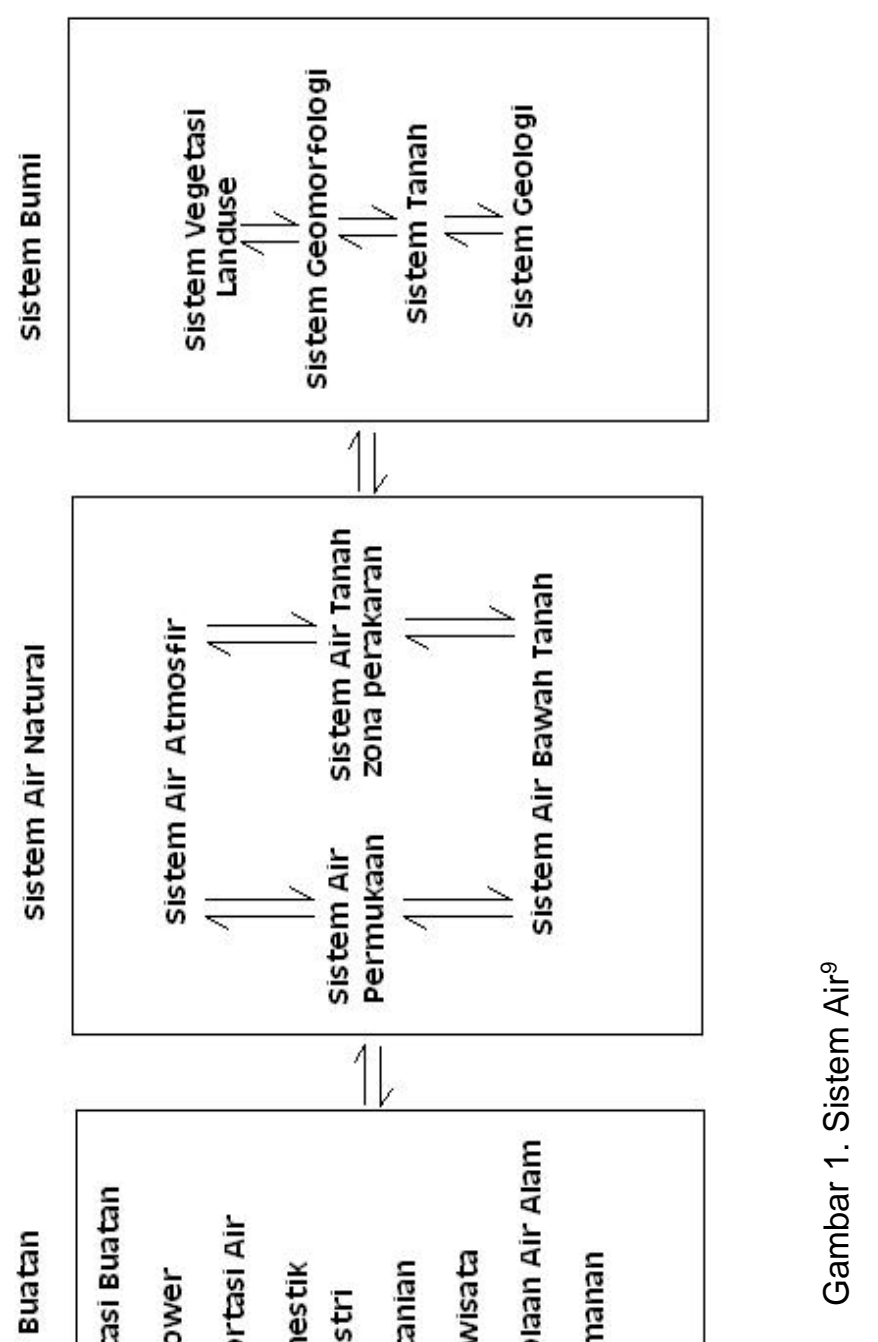

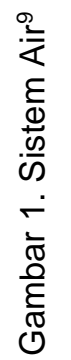




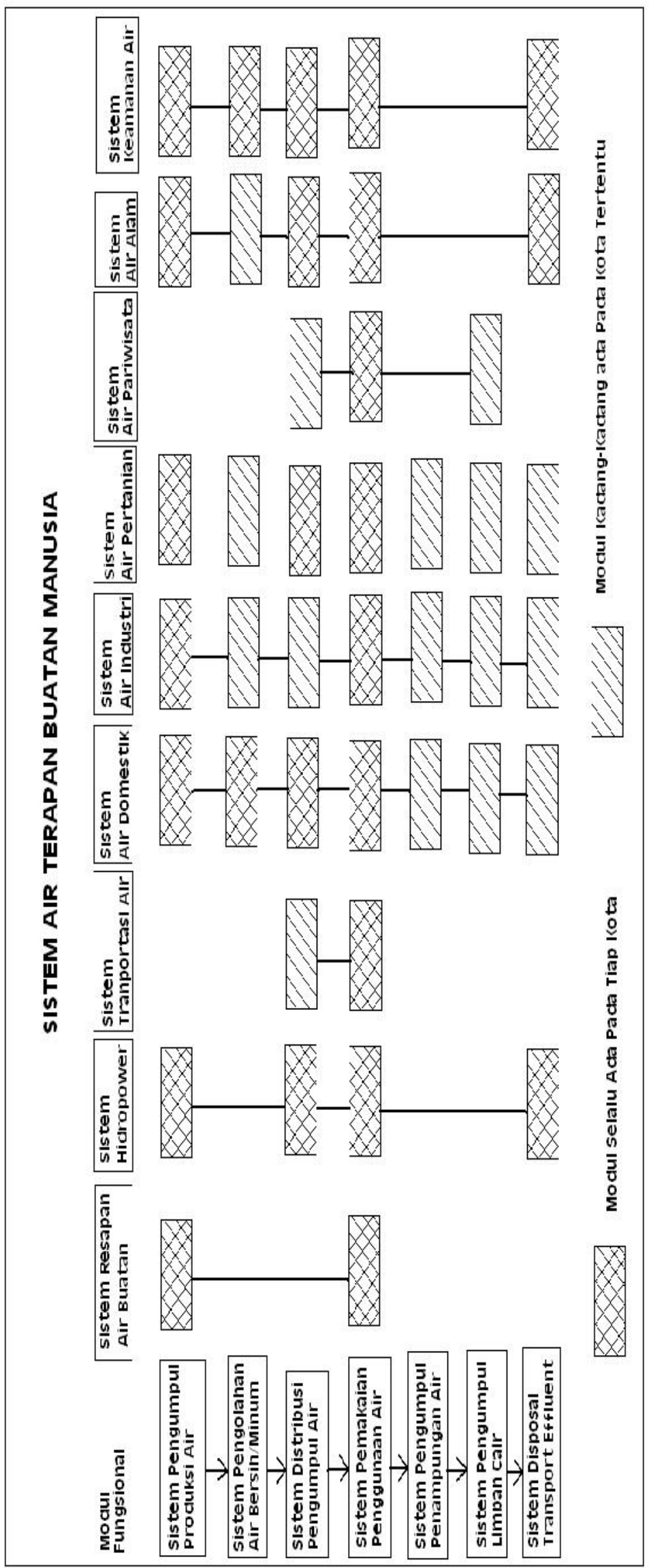

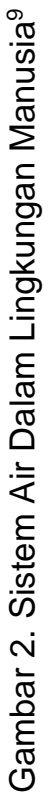

